DOI: https://doi.org/10.32839/2304-5809/2021-3-91-55

УДК 347.948

Бузина С.О., Лук'янова В.О.

Харківський науково-дослідний експертно-криміналістичний центр Міністерства внутрішніх справ України

\title{
ПРОБЛЕМИ ОЦІНКИ ВАРТОСТІ КОЛІСНИХ ТРАНСПОРТНИХ ЗАСОБІВ В РАМКАХ ТРАНСПОРТНО-ТОВАРОЗНАВЧОЇ ЕКСПЕРТИЗИ
}

\begin{abstract}
Анотація. У статті досліджено проблеми оцінки вартості колісних транспортних засобів в рамках транспортно-товарознавчої експертизи. Вивчено чинне законодавство, яке регулює механізм проведення оцінки вартості колісних транспортних засобів. Визначено значення пошкоджень колісного транспортного засобу для його оцінки. З'ясовано основні види шкоди та збитків, яких може зазнати транспортний засіб та його власник. Досліджено роль зносу колісного транспортного засобу та його комплектуючих для результатів оцінки об'екта експертизи. З'ясовано особливості фізичного та функціонального зносу, їх природу. Визначено основні етапи проведення оцінки. Визначено умови присутності зацікавлених осіб при проведенні оцінки. Визначено недоліки сучасного механізму проведення оцінки колісних транспортних засобів, дано рекомендації з їх вирішення.
\end{abstract}

Ключові слова: колісний транспортний засіб, оцінка, транспортно-товарознавча експертиза, товарознавча експертиза, законодавство.

Buzyna Serhii, Luk'ianova Viktoriia Kharkiv Scientific Research Forensic Center of the MIA of Ukraine

\section{PROBLEMS OF ESTIMATING THE COST OF WHEELED VEHICLES IN THE FRAMEWORK OF TRANSPORT AND COMMODITY EXPERTISE}

Summary. The article examines the problems of estimating the cost of wheeled vehicles in the framework of transport and commodity expertise. The current legislation regulating the mechanism for assessing the cost of wheeled vehicles has been studied. The current state and attempts to modernize these documents are clarified. The latest changes in the regulatory framework are evaluated. The positive and negative consequences of such legislative changes are indicated. The value of damage to a wheeled vehicle for its assessment is determined. The main types of damage and losses that can be incurred by the vehicle and its owner are clarified. The features of indirect losses and lost profits, the necessary conditions for their proof are determined. The role of wear of a wheeled vehicle and its components for the results of evaluation of the object of expertise is investigated. The features of physical and functional wear and tear and their nature are clarified. The potential of using transport and commodity expertise as the main means of evaluating a wheeled vehicle is studied. The theoretical value of the results of the expert examination and the significance of its conclusions for compensation of losses to the owner of the research object are determined. The main stages of the expert examination are determined. Indicated on the evaluation criteria. It is indicated that it is necessary to study the operability of a wheeled vehicle and its components. The possibility of conducting a study while driving a wheeled vehicle is clarified. The conditions for the presence of interested parties during the assessment are defined. The benefits of the results of other types of expertise for evaluating a wheeled vehicle are evaluated. The disadvantages of the modern mechanism for evaluating wheeled vehicles are identified. The disadvantages of using the commodity specialist's Bulletin during the expert examination are clarified. The problems of applying the principles of effective use of property and the object of expertise are revealed. The problems of applying the physical wear coefficient in accordance with the current legislation are studied. Recommendations are given for solving existing problems of evaluating wheeled vehicles.

Keywords: wheeled vehicle, assessment, transport and commodity expertise, commodity expertise, legislation.

$\Pi^{-1}$ остановка проблеми. Колісні транспортні засоби (КТЗ) є найпоширенішим видом транспорту i, відповідно, нанесення чи отримання ними шкоди часто є причиною проведення транспортно-товарознавчої експертизи. Під час оцінки ринкової вартості автомобіля виникає комплекс питань, які ускладнюють цей процес. Вони пов'язані з проблемою оцінки зносу КТЗ, вихідних даних, які є базою для ощінки, тощо. Цей фрактор також впливає на визначення розміру збитку завданого власнику КТЗ внаслідок дорожньо-транспортної пригоди (ДТП) чи іншої події, яка може призвести до пошкодження транспортного засобу. Необхідністю комплексного вивчення проблеми визначення вартості колісних транспортних засобів та розміру збитку завданого власнику КТЗ в ході транспортно-товарознавчої експертизи зумовлено написання цієї статті.
Аналіз останніх досліджень і публікацій. Проблемою оцінки вартості колісних транспортних засобів в рамках транспортно-товарознавчої експертизи цікавився ряд вчених, серед них А. В. Дзюбинський, В. В. Шух, Д. С. Гордієнко та інші. І. В. Рева досліджував особливості товарознавчої експертизи КТЗ, С. Й. Гонгало вивчав механізм та методику проведення експертизи цієї групи товарів, А. В. Дзюбинський з’ясовував споживчі властивості легкових автомобілів.

Виділення не вирішених раніше частин загальної проблеми. Невирішеним залишається питання вивчення проблем оцінки вартості колісних транспортних засобів в рамах транспортно-товарознавчої експертизи в умовах існування сучасного ринку, що динамічно розвивається. Окрему увагу варто приділити положенням чинного законодавства, що регулюе транспортно-то- 
варознавчу експертизу КТЗ та проблемам, що пов'язані 3 модернізацією нормативно-правової та науково-методологічної бази.

Виклад основного матеріалу. Ощінка ринкової вартості КТЗ відбувається відповідно до чинного законодавства, а саме Законів України «Про судову експертизу», «Про оцінку майна, майнових прав та професійну оціночну діяльність в Україні» та іншими нормативно-правовим актами. Сам механізм проведення транспортно-товарознавчої експертизи регулюеться чинною «Методикою товарознавчої експертизи та оцінки колісних транспортних засобів» [4]. Цей документ періодично оновлювався. Наприклад відповідно до змін від 21.10.2019 розширено перелік документів, які власник КТЗ має надати для проведення оцінки, введено принцип економічної доцільності операції ремонту, змінено значення деяких термінів та введено нові, тощо. Окрім того, цей документ скасовував попередні зміни від 29 серпня 2019 року [3].

Оновлення нормативно-правової бази свідчить про увагу законодавців до цього питання, а тому доцільно заявити про систематичну модернізацію певних положень законодавства. Проте часта зміна документів може призвести до зниження якості проведення ощінки КТЗ. Постійна необхідність освоєння нових положень методики та законів експертами ускладнюе їх роботу та знижує едективність досліджень.

Під час проведення оцінки майна експерти, як правило, найчастіше мають справу зі шкодою, заподіяною цьому майну. Розрізняють два види шкоди: пряму та непряму. Пряма шкода у контексті оцінки КТЗ полягає у пошкодженні або знищенні транспортного засобу, порушенні його цілісності або комплектності, тощо. Непряма шкода полягає у втраті потенційної вигоди, яке власник КТЗ міг би отримати у разі, якщо транспортний засіб не було б пошкоджено. Відповідно до ст. 22 Цивільного Кодексу України під упущеною вигодою розуміють «доходи, які особа могла б отримати за звичайних обставин, якби її право не було порушене» [6]. Тому, ощінюючи збитки, яких зазнав власник транспортного засобу, доцільно розглядати й втрачену вигоду. Проте варто зазначити, що підстави для відшкодування цих збитків мають бути чіткими та досить вагомими для розгляду та ухвалення судом, тобто втрата доходу має бути документально підтвердженою, а не теоретичною.

Ще одним важливим фрактором є знос КТЗ під час його експлуатащії. Його природою можуть бути умови експлуатації, природні умови. Залежно від причини, що викликала знецінення транспортних засобів, відповідно до чинного законодавства розрізняють два типи експлуатаційного зносу: фрізичний та фрункціональний. Фізичний знос полягає у частковій або повній втраті транспортним засобом чи його складниками первісних технічних та технологічних якостей. Функціональний знос означає зниження показників фрункціональних та споживчих характеристик КТЗ у порівнянні 3 аналогом, який виготовляють на момент проведення оцінки [4]. Будь-який об'єкт оцінки може піддаватися одночасно різним типам зносу, тому оцінювачів цікавить накопичений (сукупний) знос або знецінення, тобто сумарні втрати вартос- ті об'єкта ощінки. Важливість урахування обох типів зносу при оцінці КТЗ обумовлена наступними причинами: відносно невеликими нормативними термінами служби більшості транспортних засобів, що свідчить про істотність впливу фрізичного зносу на їх вартість; високою динамікою появи нових технологій, матеріалів і конструкщій транспортних засобів, що сприяе їх швидкому фрункціональному зносу [5, с. 134].

Оцінка вартості КТЗ відбувається під час транспортно-товарознавчої експертизи. Цей вид аналізу дозволяе максимально точно визначити стан транспортного засобу, виявити дефекти автомобіля, ощінити ринкову вартість автомобіля постраждалої сторони до пошкодження та після, спрогнозувати точний обсяг відновлювальних робіт. Оціночна експертиза необхідна для того, щоб оцінити шкоду, якої зазнав КТЗ, та збитки власника. Тут враховуеться ринкова вартість транспортного засобу і необхідного ремонту; сума втрати товарної вартості; доцільність і вартість ремонту; ціна придатних для реалізації залишків машини.

Першим етапом транспортно-товарознавчої експертизи $є$ вивчення документації, наданої власником транспортного засобу. Висновок експерта містить інформацію також і про власника КТЗ. Потім експерт може розпочати дослідження технічного стану КТЗ (ідентифікація, визначення технічного стану, комплектності, характеру та розміру заподіяної шкоди та ін.). Важливим моментом $\epsilon$ визначення відповідності даних документації реальному стану КТЗ та його комплектуючих, серійних номерів, наявності додаткового обладнання. Експерт також повинен зазначити пробіг КТЗ та ознаки попередньо проведеного ремонту.

Після зовнішнього огляду відбувається перевірка працездатності механізмів та пристроїв (двигуна та інших складових). За можливості оцінка працездатності може відбуватись і під час руху КТЗ. Замовник експертизи може здійснити виклик зацікавлених осіб до огляду транспортного засобу за згоди експерта, проте їх присутність не обов'язкова. У разі, якщо ці особи були присутні, експерт повинен ознайомити їх 3 результатами експертизи [2, с. 4-6].

Для оцінки вартості КТЗ можуть бути важливі результати інших видів експертизи. Наприклад, автотехнічна експертиза у разі дослідження ДТП дозволяе встановити швидкість руху транспортного засобу на різних етапах дорожньо-транспортної пригоди, причини зміни напрямку руху транспортного засобу, розрахувати час подолання певних ділянок дороги, визначити взаєморозташування транспортних засобів і пішоходів. Дані автотехнічної експертизи можуть вказати на певні пошкодження КТ3 до ДТП, що впливає на оцінку транспортного засобу після пошкодження.

Процес ощінки вартості КТЗ часто має ряд недоліків різного характеру та природи. С. І. Большаков вказуе деякі парадокси транспортнотоварознавчої експертизи. Перший - проведення оцінки експертом без врахування принципу найефективнішого використання об'єкта оцінки при визначенні його ринкової вартості. Водночас застосування принципу найефективнішого використання майна призводить до ігнорування агента упущеної вигоди. 
Другий парадокс спричинений неврахуванням умов ринку КТЗ та послуг з їх обслуговування. Часто експерти та оцінювачі використовують Бюлетень товарознавця, який містить не актуальні дані про ціни на послуги та комплектуючі. С. I. Большаков зауважуе, що доцільно здійснювати розрахунки на основі документів, які підтверджують надання послуг з відновлення чи ремонту КТЗ. Окрім того, часто Бюлетень не містить даних про конкретні КТЗ чи їх комплектуючі, а тому експерти часто застосовують найближчі до них за значенням. Такі дії знижують цінність висновку експерта.

Ще один парадокс спричинений коефріцієнтом фізичного зносу, затвердженого законодавчо. Відповідно до Методики товарознавчої експертизи та оцінки колісних транспортних засобів сума відшкодування визначається із врахуванням віку пошкодженої або знищеної деталі, які потрібно замінити. При цьому часто під час ремонту застосовують нові деталі, тобто такі, коефіцієнт фрізичного зносу яких становить 0 . Таким чином власник КТЗ отримуе відшкодування у розмірі недостатньому для оплати ремонту чи заміни деталі [1, с. 70-74].
Висновки. Оңінка КТЗ під час транспортнотоварознавчої експертизи є складним процесом, який вимагає врахування ряду факторів. Визначення вартості транспортного засобу залежить від експлуатаційного зносу, який, своєю чергою, складаеться 3 фрізичного та функціонального. Обидва чинники досить динамічні, зважаючи на особливості об'єкта оцінки, а тому вимагають великої уваги з боку експертів. Складним $е$ також питання визначення шкоди, нанесеної КТЗ та прямих і непрямих збитків, які мають бути відшкодовані власнику транспортного засобу.

На цінність висновків впливае також ряд викликів, пов'язаних з методикою проведення опінки КТЗ. Серед них найвагомішими є: постійне старіння інформації Бюлетеня товарознавця; недоліки застосування принщипів найефективнішого використання об’екта ощінки або майна; невідповідність системи ощінки збитків, що мають бути відшкодовані, реальним умовам відновлення КТЗ; тощо. Розв'язання цих проблем залежить від модернізації законодавства та науково-методологічної бази, що стосуеться транспортно-товарознавчої експертизи у напрямку чіткішого ï̈ врегулювання та постійної актуалізації інформації про потенщійні об’екти.

\section{Список літератури:}

1. Большаков С. І. Принцип об’ективності оцінки вартості збитків, завданих власнику колісного транспортного засобу. Матеріально-технічне забезпечення аграрної сфери. 2015. № 6. С. 67-76.

2. Данілін С. С. Загальна характеристика авто товарознавчої експертизи. Часопис Національного університету "Острозька академія". Серія "Право". 2015. № 1(11). С. 1-12.

3. Про затвердження Змін до Методики товарознавчої експертизи та оцінки колісних транспортних засобів : Наказ Міністерства юстиції України від 21.10.2019 № 3207/5/1033. URL: https://zakon.rada.gov.ua/laws/show/ z1129-19\#Text (дата звернення: 23.02.2021).

4. Про затвердження Методики товарознавчої експертизи та оцінки колісних транспортних засобів : Наказ Міністерства юстиції України від 24 листопада 2003 р. № 142/5/2092. URL: https://zakon.rada.gov.ua/laws/ show/z1074-03\#n15 (дата звернення: 23.02.2021).

5. Трифонов Н. Ю. Характеристика накопленного износа автомобилей методами фринансовой математики. Белорусский эконолический журнал. 2014. № 3. С. 133-143.

6. Цивільний кодекс України. Відомості Верховної Ради України. 2003. URL: https://zakon.rada.gov.ua/laws/ show/435-15\#Text (дата звернення: 22.02.2021).

\section{References:}

1. Bolshakov S. I. (2015) Pryntsyp obiektyvnosti otsinky vartosti zbytkiv, zavdanykh vlasnyku kolisnoho transportnoho zasobu [The principle of objectivity of estimating the value of losses caused to the owner of a wheeled vehicle]. Materialno-tekhnichne zabezpechennia ahrarnoi sfery, no. 6, pp. 67-76.

2. Danilin S. S. (2015) Zahalna kharakterystyka avto tovaroznavchoi ekspertyzy [General characteristics of auto commodity expertise]. Chasopys Natsionalnoho universytetu "Ostrozka akademiia". Seriia "Pravo", no. 1(11), pp. 1-12.

3. Pro zatverdzhennia Zmin do Metodyky tovaroznavchoi ekspertyzy ta otsinky kolisnykh transportnykh zasobiv: Nakaz Ministerstva yustytsii Ukrainy vid 21.10.2019 № 3207/5/1033 [On approval of amendments to the methodology of commodity expertise and evaluation of wheeled vehicles: Order of the Ministry of Justice of Ukraine No. 3207/5/1033 dated 21.10.2019]. URL: https://zakon.rada.gov.ua/laws/show/z1129-19\#Text (accessed 23 February 2021).

4. Pro zatverdzhennia Metodyky tovaroznavchoi ekspertyzy ta otsinky kolisnykh transportnykh zasobiv: Nakaz Ministerstva yustytsii Ukrainy vid 24 lystopada 2003 r. № 142/5/2092 [On approval of the methodology of commodity expertise and evaluation of wheeled vehicles: Order of the Ministry of Justice of Ukraine No. 142/5/2092 of November 24, 2003]. URL: https://zakon.rada.gov.ua/laws/show/z1074-03\#n15 (accessed 23 February 2021).

5. Trifonov N. Ju. (2014) Harakteristika nakoplennogo iznosa avtomobilej metodami finansovoj matematiki [Characteristics of accumulated car wear by methods of financial mathematics]. Belorusskij jekonomicheskij zhurnal, no. 3, pp. 133-143.

6. Tsyvilnyi kodeks Ukrainy [Civil Code of Ukraine]. Vidomosti Verkhovnoi Rady Ukrainy. 2003. URL: https://zakon.rada.gov.ua/laws/show/435-15\#Text (accessed 22 February 2021). 